\title{
Missionaries and Indigenous Education in the 19th- Century British Empire. Part II: Race, Class, and Gender
}

\author{
Felicity Jensz*
}

Cluster of Excellence for Religion and Politics, Westfälische Wilhelms-Universität Münster

\begin{abstract}
Missionaries were major providers of education to Indigenous peoples in the colonial world. They hoped both to convert their pupils to Christianity as well as to ensure that their converts had a Christian environment in which aspects of Western education were taught within the class room. The relationship between missionaries, Governments and Indigenous peoples was, however, often strained as has been demonstrated in Part I of this two-part article, which examined various responses in different geopolitical and social settings to missionary education. Part II examines some of the scholarly debates and research directions surrounding how missionaries, as some of the first as well as the longest serving providers of education to Indigenous peoples, transmitted and instilled Western notions of race, class and gender to those peoples amongst whom they worked. Although the study of missions has received increased attention in the last few decades within areas such as anthropology, gender studies, post-colonial studies and area studies, there are still many aspects of missionary schooling that remain understudied. This research overview therefore also provides some future directions for the study of missionaries and their education of Indigenous and non-European peoples in the long 19th century.
\end{abstract}

The schooling of the so-called 'heathen' was of paramount importance for all 19th century missionary organizations. In some places missionaries established schools before churches, indicating the central position that schooling had in the missionary endeavor. ${ }^{1}$ The provision of education to Indigenous and non-European peoples was a means to encourage non-Europeans' participation in the missionary endeavor, and to draw people into the sphere of influence of the mission. It was also, like contemporaneous schooling in Europe, a way to instill a "moral technology" upon the next generation. ${ }^{2}$ Missionaries often saw themselves as a moral, stabilizing force for Indigenous peoples that had been caught up amongst the disarray brought about by the great social transformations that colonialism brought with it. Yet through schooling missionaries themselves hoped to enact a transformative process from 'heathen' and 'uncivilized' native to 'civilized' and Christian convert.

For evangelical Protestants the reading of the Bible was an essential skill needed to open the Word of God to individuals, with schooling being the means to teach people to read the Bible for themselves and to help form better Christians. Thus, at the beginning of the 19th century missionaries believed that schooling non-Europeans in Western, Christian knowledge would 'raise' the so-called 'heathen', and bring him or her into the folds of 'civilization', yet by the end of the century, missionaries - under the influence of increasingly proscriptive governmental education policies; the ambivalent or negative attitudes of colonial society towards indigenous education; and the lack of outstanding success in 'raising' their protégée to the standards deemed necessary to assimilate into 
European colonial society - had often replaced this aim for a more humble desire to provide vocational training to their pupils.

In Part I of this two-part article, I argued that the role of missionaries in Indigenous education was ambiguous and often contradictory. The examination of Church-State relations and Indigenous actions and reactions in that article demonstrated that although the aim of missionary education remained constant - that is to bring people to Christianity-missionaries needed to respond dynamically to specific geographical, political, and social situations. Moreover, I argued that the recent focus upon Church-State relations and Indigenous actions and reactions in terms of missionary education stemmed from an increased historical awareness of the need both for a nuanced reading of the missionary endeavor as well as to include Indigenous experiences in the historical narrative. As mentioned in Part I, methodological shifts have encouraged a broader academic focus upon missionary work, which, in turn, has shifted missionary history beyond the narrow confines of Church or religious history. The work stemming from gender, subaltern, and postcolonial studies has also had a major impact on broadening our understanding of missionary work. This essay will explore the developments in and prospects for how themes of race, class, and gender are examined in scholarship on missionary education.

\section{Race and Class}

The 17th-century natural philosopher John Locke's idea that the mind was a blank slate- a tabula rasa-was broadly circulated throughout the 19th century, and had currency amongst those who thought about education. Philosophers in the 19th century were ambivalent about the capacity of the minds of 'primitive peoples' for Western education, yet positive missionary experiences had demonstrated that if 'heathen' children were instructed in Western missionary education from a young age, they could be raised as Christians and could proficiently learn Western forms of knowledge. ${ }^{3}$ James Campbell has argued that: "For all its manifest limitations, 19th century missionary education rested on assumptions of liberal universalism." Yet, missionaries were also affected by, and effected, the hardening of racial determination at the end of the 19th century. ${ }^{5}$ A shift is apparent in missionary writings from those in the 18th century that deemed the so-called 'primitive peoples' to be innocent and child-like, to writings in the 19th century that placed many non-Europeans on the lowest points of the racial-cultural scale. ${ }^{6}$ Added to this was the assumption that the broader ideas of welfare and of educating the poor in Britain through charity and Sunday schools ought to be applied to missionary efforts to educate non-European peoples. ${ }^{7}$ Moreover, there were analogies between the poor laws of Britain, which also related to the treatment of peoples of lower-class in the colonies, and the treatment of Indigenous peoples. Missionaries engaged in schooling Indigenous peoples with the belief that education would help 'raise' them to the level of workingclass whites. For example, in Canada in the 19th century Protestant and Catholic missionaries undertook the bulk of the humanitarian work amongst First Nation peoples, including education and medical treatment, but educated them generally only to the level received by the poorest class of European-Canadians. ${ }^{8}$ This conflation of race and class was also evident within colonial Australia. ${ }^{9}$

The position that an Indigenous or non-European person could hold in society was, in part, contingent upon how much education the person received. In Australia, for example, Aboriginal children were only taught rudimentary skills-mostly by missionaries-that would not allow them to fully participate in the colonial society, even if they had wanted to. ${ }^{10}$ Participation in society is also contingent upon the capacity to communicate 
in mutually intelligible languages, and, since culture is transmitted though language, the language of instruction was an important consideration not only for missionaries, but also for all colonial governments. Should missionaries teach in the vernacular, as the Orientalists proposed for India? Or in English, as proposed by the 'Anglicists', 11 even though it was neither the native language of the Indigenous peoples, nor, in many cases, the native language of the missionaries themselves? Most missionary groups, suggests Norman Etherington, preferred to teach in local languages; a method which has helped to codify, and in some cases preserve, Indigenous languages, ${ }^{12}$ but which was ultimately encouraged by missionaries so that they could more quickly spread the Christian message. ${ }^{13}$ Moreover, some missionaries in Africa were concerned that if they taught their pupils too much English then they may alienate their African converts from broader social networks, and thus reduce their accessibility to further potential converts. ${ }^{14}$ Yet, in the context of India, T. B. Macaulay's 1835 "Minute on Education" laid the path for English-language schools for a few elites, with the idea that there would be a filtration effect by which other parts of society would benefit and learn from those elite who had received English language training. ${ }^{15}$ The Scottish missionary Alexander Duff advocated the use of English in Indian schools, for he believed that Sanskrit was an 'evil' language filled with cultural falsehoods. ${ }^{16}$ The English-language education of an elite class in India, however, provided fodder for anxieties in other colonies as English-language schooling was perceived to have contributed to the Indian Mutiny of 1857 , with colonial officers, white settlers, and missionaries wishing to avoid similar experiences, especially in Africa. ${ }^{17}$

Writing on Kenya, Robert Strayer has suggested that an intellectual shift occurred in British thought in the late 19th century, in which Africans were no longer seen as being able to rise above their perceived state of cultural inferiority with the help of Western education (the "conversionism" perspective), rather they were deemed biologically inferior and thus unable to be improved through Western education (the "trusteeship" perspective). ${ }^{18}$ Strayer further argues that the consequences for missionary education were such that it was deemed questionable whether there was any benefit in providing Africans with an academic education in English. The introduction of English-language schooling was thus contested in Africa, however, by the end of the century English dominated with its use legislated through governmental acts and furthermore connected to governmental funding for mission schools. ${ }^{19}$ Although missionaries were not always in unanimous agreement with governmental English-language policies, one commonality that emerges is that race, class, and the perceived capacity for English-language study were intertwined concepts, all of which influenced whom missionaries saw as target audiences and what was taught.

\section{Gender}

Despite the fact that the majority of British missionaries sent out in the 19th century were women, and that Indigenous and non-European women made up a substantial population on mission stations, gender, as an analytical concept, has not been applied in the history of missions until relatively recently. ${ }^{20}$ Mission schools were themselves gendered sites. For example, female missionary teachers were seen as the most appropriate teachers for female pupils and their presence was thus desired, as exemplified by female missionaries for the exclusively female space of the Zenana in India. ${ }^{21}$ The increase in the number of female teachers in Europe and the colonies reflected the changing British class structure, yet at the same time female missionary teachers in the colonies often emphasized domesticity and enforced conservative gender norms. ${ }^{22}$ Yet, missionary education also 
functioned as tool of emancipation for women of all cultures, including the British. In India for example, missionary education of females was deemed a way to extract them from the perceived dangers of traditional practices such as sati and female infanticide. ${ }^{23}$ For British women also, positions as teachers, nurses and doctors in the mission field ${ }^{24}$ provided them with professional opportunities for emancipation from gender ideals in the home country. ${ }^{25}$ However, whether missionary organizations themselves encouraged such emancipation from normative gender roles through professional work such as teaching has not been sufficiently studied. We do know that single women were actively recruited to be teachers by Protestant missionary societies not least of all because they were generally in greater supply and cost less than their male counterparts, ${ }^{26}$ with Catholic nuns also playing a significant role in teaching. ${ }^{27}$ Thus, missionary education provided an opportunity not only for European but also for non-European women to escape strong cultural norms. ${ }^{28}$

However, in some places, such as Southern Rhodesia, the education of women was neglected by missionaries as well as European settlers and officials into the 20 th century. ${ }^{29}$ This omission of women from spheres of Western missionary education was to some degree fed by anxiety over losing control over women and their sexuality. As Ann Stoler has argued in the context of the Dutch West Indies, female native sexuality was a major point of anxiety for white colonial officers in the 19th and twentieth centuries. ${ }^{30}$ Similar concerns were expressed in the British Empire, with missionaries being very concerned with creating and maintaining appropriate sexual behavior amongst their charges. ${ }^{31}$ When women were educated, it was often with middle-class femininity in mind, which demanded a cultural transformation of those non-European women to conform to European notions of femininity. ${ }^{32}$ Despite such cultural transformations, missionaries often collapsed the categories of race and class and preferentially arranged marriages of their protégée amongst people of similar racial background, irrespective of the proposed spouses' educational achievements. ${ }^{33}$ In places as far apart as Uganda and Hong Kong, the teaching of female pupils within missionary schools was undertaken with similar ideals of creating ideal female converts; ideals that often limited women in comparison to their traditional roles, or did not take into account female aspirations. ${ }^{34}$ Fiona Leach has argued that in Africa such missionary education for girls generally "privileged male interests and perceived male needs." ${ }^{35}$ Gender-specific secular subjects such as needlework were often taught in mission schools with the expectation that this would prepare native women to be good Christian wives for their native Christian husbands. Moreover, needlework enabled women to pragmatically provide clothes for mission residents, as well as to obtain extra income through selling their products. Needlework samples were also used as missionary propaganda in the metropolis. ${ }^{36}$ Yet for all the research on how non-European females were shaped through missionary encounters and education, there has been little research undertaken on how masculinity - both for male missionaries as well as nonEuropeans men-was shaped through missionary encounters, ${ }^{37}$ or, especially pertinent for this essay, through missionary education.

\section{Conclusion and further areas of research}

Both Part I and II of this article have highlighted some important themes currently influencing the scholarship on missionary education, and provided some historiographical insight as to the development of such avenues of research. As has been seen in Part I, the examination of mission history outside of the realms of religious and Church history had led to a broadening of perspectives as to the role of Church-State relations in missionary 
education as well as to the various ways in which Indigenous peoples have engaged in, and disengaged from missionary education. The scholarship has moved from a position in which Indigenous peoples were seen as purely reacting to missionary education, to being aware of the complex negotiations, interactions, and encounters surrounding the provision of schooling on mission stations. Part II has demonstrated that the dynamic interactions between various social expectations of British and non-British peoples over missionary education had both the potential to solidify and to disturb the categories of gender, class and race on the mission station as well as in broader colonial and British social settings. Although numerous themes were examined separately in the two parts of this essay, the examination of mission history from a wide variety of disciplines and academic perspectives has demonstrated that categories are messy and often blurred. This in itself is an indication of the continued need for detailed analysis. However, there still remains a tension between examining missionary history through in-depth case studies, or through large-scale comparative studies, for both offer advantages and both have their limitations.

Moreover, research into missionary education remains geographically patchy. Despite the abundance of research on the history of missionary education in India and British Africa, there has been relatively little material published on missionary education in Oceania or South-East Asia. This lack of research may, in some places, be due to the perceived insignificant effects of missionary education. ${ }^{38}$ The same cannot, however, be said of the Pacific, where in places such as the Solomon Islands, missionaries were the only providers of education until well into the 20th century. ${ }^{39}$ Furthermore, there has been comparatively little written about the New England-type settler colonies, ${ }^{40}$ with more being written about Canada than Australia or New Zealand. More comparative research would be welcome, especially since comparisons between these three former colonies would illuminate their assimilative and segregationalist policies. ${ }^{41}$

Although some work has been undertaken on the effects that missionary education had on educational policy in India and also on how this was transferred to educational policy in Africa, ${ }^{42}$ the transfer process of government policy to other parts of the empire and its subsequent effects on missionary education remains less understood. ${ }^{43}$ Over thirty years ago, Patricia Rooke noted that "evangelicalism has not generally been examined in terms of pedagogical transfers or educational influences." 44 Her statement still rings true for, apart from the transfer of LMS educational techniques from the slums of London to the South Pacific, and some recent work on India, ${ }^{45}$ most of the work that has been undertaken on educational transfers refers more to moments in which missionaries were compelled to fit within external frameworks, rather than illuminating any pedagogical transfers that evangelicals initiated themselves. ${ }^{46}$ Examples such as the communication of educational ideas between England and India, ${ }^{47}$ or the later work of the PhelpsStokes Commission on education in British Eastern and Western Africa in the 1920s, ${ }^{48}$ underscore this point. It is also somewhat surprising that, despite missionaries being members of one of the most connected professions in the 19 th century, ${ }^{49}$ there remains a paucity of studies pertaining to how individual missionaries, or missionary societies, transferred and communicated information to each other about different pedagogical methods. This is especially surprising since missionaries were well aware of each other's presence in the field, and missionary education was a topic of intense debate at missionary conferences throughout the 19th century, ${ }^{50}$ culminating in a systematic consideration of African education at the World Missionary Conference at Edinburgh in $1910 .{ }^{51}$

Whilst there is no doubt that Indigenous peoples actively partook in missionary education, there has been relatively little recent research undertaken on pupil numbers and on 
how representative these numbers might be of entire populations. ${ }^{52}$ Research also remains limited on the economics of missionary schools. We know that schools were required to raise funds for both structural aspects as well as personnel. Knowledge of just how this was achieved remains, however, sketchy. Educational sociology might be useful in extending knowledge in these areas. ${ }^{53}$ More research also needs to be undertaken into mission schools as sites of cross-cultural encounters, not just between Western missionaries and non-European pupils, but also between white and non-European pupils and between pupils of different cultural backgrounds. Although newer trends in 19th century imperial history-which has moved from geographically specific studies to broader transnational, globally interlaced histories, with a strong focus upon cultural history ${ }^{54}$-have emerged, the study of missionary schooling has not fully profited from these new directions. Much work has been undertaken on the cultural transformations that missionary schooling could and did engender (through language and gender constructs), as well as on the agency of non-Europeans in embracing or rejecting missionary schooling. Less has, however, been written about hybridity, ${ }^{55}$ time or space, ${ }^{56}$ and how these aspects also effected cultural transformations.

Thus, although the study of missionary education is increasing in volume and broadening in scholarly focus, there are still numerous aspects that remain understudied. The work that has nevertheless been undertaken has profited from the insights of anthropology, post-colonial theory, and the need to see the relationship between missionaries and governments in a nuanced light. Such work has added to our understanding of how, in the dynamic and constantly changing environments of colonial societies, missionaries were the instigators of schooling, yet their work was contingent on both native as well as governmental engagement. One constant in this dynamic was the belief of missionary societies' in their positions as the most appropriate organizations for providing indigenous peoples with Western, and implicitly religious, schooling, in order to protect indigenous peoples from the perceived negative effects and aspects of Western civilization. However, during the course of the 19th century secular education was increasingly seen as a part of the modern nation state, and thus, missionaries needed to legitimize their continued involvement in indigenous education. Research on missionary involvement in indigenous education has aided our knowledge of how religious and humanitarian ideas for indigenous education were enacted and maintained in increasingly structurally secular colonial sites; sites that were themselves often on the cusp of becoming nation states. Further research into all of these aspects would contribute to our understanding of the commonalties and differences of colonial missionary education to vast numbers of the world's population in the 19th century, and to the social, political, economic and religious changes that these schools effected.

\section{Short Biography}

Felicity Jensz's research focuses upon the relationships between missionaries, Indigenous peoples, and governments in the 19th-century British colonial world, with a particularly focus on the transnational aspects of these relationships. She has a interest in Germanspeaking Moravian missionaries and has published papers on this group in Aboriginal History, Journal of the History of Collections, and Journal of Religious History. Her book Moravian Missionaries in the British Colony of Victoria, Australia (Brill, 2010) examined the complex tensions between non-British missionaries and British colonial governance. Current research focuses upon missionary education as well as missionary periodicals in the 19th century. She is a Postdoctoral Research Fellow in the Cluster of Excellence for Religion 
and Politics at the Westfälische Wilhelms-Universität Münster, Germany and an Honorary Fellow in the School of Historical Studies at the University of Melbourne, Australia, where she obtained her Ph.D.

\section{Notes}

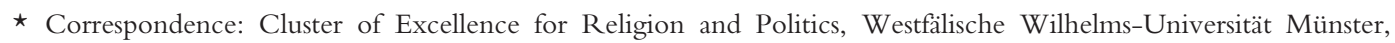
Johannisstr. 1-4, 48143 Münster, Germany. Email: felicity.jensz@uni-muenster.de.

1 See for example: William H. Taylor, 'The Presbyterian Educational Impact in Eastern Nigeria', Journal of Religion in Africa, 14/3 (1983): 225; Felicity Jensz, German Moravian Missionaries in the British Colony of Victoria, Australia, 1848-1908: Influential Strangers (Leiden: Brill, 2010), 121.

2 Jorge Ramos do Ó, 'Government of the Soul and Genesis of the Modern Educational Discourse (1879-1911)', Paedagogica Historica, 41/1\&2 (2005): 243-57.

${ }^{3}$ See for example: Anne O'Brien, 'Creating the Aboriginal Pauper: Missionary Ideas in Early 19th Century Australia', Social Sciences \& Missions, 21/1 (2008): 16.

${ }^{4}$ James Campbell, 'Models and Metaphors: Industrial Education in the United States and South Africa', in Ran Greenstein (ed.), Comparative Perspectives on South Africa, (Houndmills, Basingstoke, Hampshire, \& London: Macmillan Press, 1998), 123.

5 For changing attitudes towards race see for example: Nancy Stepan, The Idea of Race in Science: Great Britain 1800-1960 (Oxford: St Antony's/Macmillan Series, 1982); Richard A. Jones, 'Race and Revisability', Journal of Black Studies, 35/5 (2005): 612-32. For missionary contributions to the construction of the 'other', including hardening racial categorizations see: Anna Johnston, Missionary Writing and Empire, 1800-1860 (Cambridge: Cambridge University Press, 2003), passim; Mark Francis, 'The "Civilizing" of Indigenous People in Nineteenth-Century Canada', Journal of World History, 9/1 (1998): 51-87.

${ }^{6}$ Although the hardening of racial boundaries was a general tendency amongst colonial governments, the mission response expressed itself differently in various colonies. See for example: Jeffrey Cox, 'Review of: Missionary Education and Empire in Late Colonial India, 1860-1920, by Hayden J. A. Bellenoit', Victorian Studies, 51/4 (2009): 749-51.

7 See for example: Thomas O. Beidelman, 'Contradictions between the Sacred and the Secular Life: The Church Missionary Society in Ukaguru, Tanzania, East Africa, 1876-1914', Comparative Studies in Society and History, 23/1 (1981): 79; Larry Prochner, Helen May, and Baljit Kaur, " "The Blessings of Civilisation": Nineteenth-Century Missionary Infant Schools for Young Native Children in Three Colonial Settings - India, Canada and New Zealand 1820s-1840s', Paedagogica Historica, 45/1\&2 (2009): 85; Patricia T. Rooke, 'Missionaries as Pedagogues: A Reconsideration of the Significance of Education for Slaves and Apprentices in the British West Indies, 1800-1838', History of Education, 9/1 (1980): 69; Manali Desai, 'Indirect British Rule, State Formation, and Welfarism in Kerala, India, 1860-1957', Social Science History, 29/3 (2005): passim.

${ }^{8}$ See: Kristin Burnett, 'Building the System: Churches, Missionary Organizations, the Federal State, and Health Care in Southern Alberta Treaty 7 Communities, 1890-1930', Journal of Canadian Studies, 41/3 (2007): 21.

9 See for example: Amanda Barry, "Equal to Children of European Origin": Educability and the Civilising Mission in Early Colonial Australia', History Australia, 5/2 (2008): 41.1-41.16; O'Brien, 'Creating the Aboriginal Pauper: Missionary Ideas in Early 19th Century Australia', passim.

10 According to A. R. Welch, the education of Aboriginal Australians was akin to internal colonialism. See: A. R. Welch, 'Aboriginal Education as Internal Colonialism: The Schooling of an Indigenous Minority in Australia', Comparative Education, 24/2 (1988): 207.

${ }^{11}$ See for example: Tim Allender, 'Bad Language in the Raj: The 'Frightful Encumbrance' of Gottlieb Leitner, 1865-1888', Paedagogica Historica, 43/3 (2007): 384; Sanjay Seth, Subject Lessons. The Western Education of Colonial India (Durham and London: Duke University Press, 2007), 95.

${ }_{12}$ Paul Landau, 'Language', in Norman Etherington (ed.), Mission and Empire. Oxford History of the British Empire. Companion Series, (Oxford, New York: Oxford University Press, 2007), 194-215.

${ }_{13}$ Norman Etherington, 'Education and Medicine', in Norman Etheringon (ed.), Missions and Empire, (Oxford: Oxford University Press, 2005), 266.

${ }^{14}$ See: Aaron Windel, 'British Colonial Education in Africa: Policy and Practice in the Era of Trusteeship', History Compass, 7/1 (2009): 5.

${ }^{15}$ Tim Allender, 'Learning Abroad: The Colonial Educational Experiment in India, 1813-1919', Paedagogica Historica, 45/6 (2009): 732 .

16 Robert Eric Frykenberg, 'Modern Education in South India, 1784-1854: Its Roots and Its Role as a Vehicle of Integration under Company Raj', The American Historical Review, 91/1 (1986): 53.

17 See: Godfrey N. Brown, 'British Educational Policy in West and Central Africa', The Journal of Modern African Studies, 2/3 (1964): 365 . 
18 Robert W. Strayer, 'The Making of Mission Schools in Kenya: A Microcosmic Perspective', Comparative Education Review, 17/3 (1973): 316-7.

19 Timothy A. Awoniyi, 'The Yoruba Language and the Formal School System: A Study of Colonial Language Policy in Nigeria, 1882-1952', The International Journal of African Historical Studies, 8/1 (1975): 66-67.

${ }^{20}$ For an overview of the scholarship on gender and missions see: Elizabeth Prevost. 'Assessing Women, Gender, and Empire in Britain's Nineteenth-Century Protestant Missionary Movement', History Compass 7/3 (2009): 76599.

21 The Zenana helped to construct both Indian and English notions of femininity and in providing female missionary teachers and medical missionaries to the Zenana social change was also engendered in the metropolis. See for example: Parna Sengupta, "Teaching Gender in the Colony the Education Of "Outsider" Teachers in Late-Nineteenth-Century Bengal', Journal of Women's History, 17/4 (2005): 397-415; Eliza F. Kent, 'Tamil Bible Women and the Zenana Missions of Colonial South India', History of Religions, $39 / 2$ (1999): 117-49; Antoinette Burton, 'Contesting the Zenana: The Mission to Make "Lady Doctors for India”, 1874-1885', Journal of British Studies, 35/3 (1996): 368-97.

22 Joyce Goodman, " "Disposed to Take the Charge": British Women and the Management of Female Education, 1800-37', Historical Studies in Education, 11/1 (1999): 62.

23 See for example: Tim Allender, 'Anglican Evangelism in North India and the Punjabi Missionary Classroom: The Failure to Educate the 'Masses', 1860-77', History of Education, 32/3 (2003): 284; George Bartle, 'The Role of the British and Foreign School Society in Elementary Education in India and the East Indies 1813-75', History of Education, 23/1 (1994): 220-1.

24 See: Jeffrey Cox, The British Missionary Enterprise since 1700 (New York and London: Routledge, 2008), 17; Dana L. Robert, 'The Influence of American Missionary Women on the World Back Home', Religion and American Culture: A Journal of Interpretation, 12/1 (2002): 68.

25 As Dana Robert has argued the overseas medical mission gave American women a chance to practice medicine during a time when many Americans were opposed to female doctors. See: Robert, 'The Influence of American Missionary Women on the World Back Home', 70. See also: Ruth Watts, 'Education, Empire and Social Change in Nineteenth Century England', Paedagogica Historica, 45/6 (2009): 779. For the professionalization of women missionaries, see for example: Tanya Fitzgerald, “"To Unite Their Strength with Ours” , Journal of Pacific History, 39/2 (2004): 147-61; Jane Haggis, " "A Heart That Has Felt the Love of God and Longs for Others to Know It": Conventions of Gender, Tensions of Self and Constructions of Difference in Offering to Be a Lady Missionary', Women's History Review, 7/2 (1998):171-93; Elizabeth Prevost, 'Married to the Mission Field: Gender, Christianity, and Professionalization in Britain and Colonial Africa, 1865-1914', Journal of British Studies, 47/4 (2008): 796-826.

26 See for example: Burnett, Building the System, 20.

27 There is, however, a paucity of research on the role of nuns as teachers in British colonies.

28 For comments on European women see: Etherington, 'Education and Medicine', 262-3. For an example of Bengali women escaping social norms through being trained as missionary teachers see: Sengupta, 'The Education of "Outsider" Teachers', passim.

29 Carol Summers, " "If You Can Educate the Native Woman...": Debates over the Schooling and Education of Girls and Women in Southern Rhodesia, 1900-1934', History of Education Quarterly, 36/4 (1996): 452.

30 See for example: Ann L. Stoler, 'Making Empire Respectable: The Politics of Race and Sexual Morality in 20th-Century Colonial Cultures’, American Ethnologist, 16/4 (1989): 634-60.

31 See for example: Felicity Jensz, 'Controlling Marriages: Friedrich Hagenauer and the Betrothal of Indigenous Western Australian Women in Colonial Victoria', Aboriginal History, 34 (2010): 35-54

32 See for example: Bastian, Misty L., 'Young Converts: Christian Missions, Gender and Youth in Onitsha, Nigeria 1880-1929', Anthropological Quarterly, 73/3 (2000): 154.

33 See for example: Katherine Ellinghaus, Taking Assimilation to Heart. Marriages of White Women E Indigenous Men in the United States \& Australia, 1887-1937 (Lincoln \& London: University of Nebraska Press, 2006).

34 See for example: Patricia Pok-kwan Chiu, “'A Position of Usefulness”: Gendering History of Girls' Education in Colonial Hong Kong (1850s-1890s)', History of Education, 37/6 (2008): 789-805; Holly Elisabeth Hanson, 'Indigenous Adaptation: Uganda's Village Schools, Ca. 1880-1937', Comparative Education Review, 54/2 (2010): 155-74.

35 According to Leach, the relationship between European and African women as negotiated through education is a neglected aspect of mission and colonial studies. See: Fiona Leach, 'African Girls, Nineteenth-Century Mission Education and the Patriarchal Imperative', Gender and Education, 20/4 (2008): 335-36.

36 See for example: Silke Strickrodt, 'African Girls' Samplers from Mission Schools in Sierra Leone (1820s to 1840s)', History in Africa, 37 (2010), 203-8.

37 An exception is: Rhonda A. Semple, 'Missionary Manhood: Professionalism, Belief and Masculinity in the Nineteenth-Century British Imperial Field', Journal of Imperial \& Commonwealth History, 36/3 (2008): 397-415.

38 See for example: Ooi Keat Gin, 'Sarawak Malay Attitudes Towards Education During the Period of Brooke Rule, 1841-1946', Journal of Southeast Asian Studies, 21/2 (1990): 340-59. 
39 David Hilliard, 'Colonialism and Christianity: The Melanesian Mission in the Solomon Islands', The Journal of Pacific History, 9 (1974): 112.

40 For a definition of "New England" Settler colonies see: Jürgen Osterhammel, Kolonialismus. Geschichte. Formen. Folgen, 5th edn., (München: C. H. Beck, 2006), 11-2.

41 See for example: Larry Prochner, 'Early Childhood Education Programs for Indigenous Children in Canada, Australia and New Zealand: An Historical Review', Australian Journal of Early Childhood, 29/4 (2004): 7-16; Prochner, May, and Kaur, “"The Blessings of Civilisation”, , passim; Julie Evans, Patricia Grimshaw, David Phillips, and Shurlee Swain, Equal Subjects, Unequal Rights: Indigenous Peoples in British Settler Colonies, 1830-1910 (Manchester: Manchester University Press, 2003), passim.

42 See for example: Seppo Sivonen, White-Collar or Hoe Handle? African Education under British Colonial Policy 19201945 (Helsinki: Suomen Historiallinen Seura, 1995), 51-9.

43 There are, of course, exceptions, however these are often cursory overviews of the process, rather than in-depth analysis. For a Kenyan example see: John Anderson, The Struggle for the School. The Interaction of Missionary, Colonial Government and Nationalist Enterprise in the Development of Formal Education in Kenya (London: Longman, 1970$), 10$. For an example pertaining to post-World War I Fiji see: Clive Whitehead, 'Paternalism and Educational Policy in Colonial Fiji', New Zealand Journal of Educational Studies, 16/1 (1981): 51-7.

44 Rooke, 'Missionaries as Pedagogues,' 75.

45 See: Hayden J.A Bellenoit, Missionary Education and Empire in Late Colonial India, 1860-1920 (London: Pickering \& Chatto, 2007), especially chapter 1.

46 An exception is the brief mention John Webser Grant gives to the use of the latest international pedagogical methods used by missionaries in Upper Canada in the mid-nineteenth century. See: John Webster Grant, Moon of Wintertime. Missionaries and the Indians of Canada in Encounter since 1534 (Toronto, Buffalo \& London: University of Toronto Press, 1984), 181.

47 An example of the influence of educational practices in the colonies back to the metropolis, from there throughout the empire is the transmission of the Monitorial System of education from Madras to England and beyond. See: Jana Tschurenev, 'Diffusing Useful Knowledge: The Monitorial System of Education in Madras, London and Bengal, 1789-1840', Paedagogica Historica, 44/3 (2008): 245-64; Jana Tschurevev, 'Incorporation and Differentiation: Popular Education and the Imperial Civilizing Mission in Early Nineteenth Century India', in Carey A. Watt and Michael Mann (eds.), Civilizing Missions in Colonial and Postcolonial South Asia. From Improvement to Development, (London: Anthem Press, 2011), 93-124. For the introduction of the Monitorial System into missionary schools in the Bahamas see: Rodney Bain, 'Missionary Activity in the Bahamas, 1700-1830', in Brian Holmes (ed.), Educational Policy and the Mission Schools. Case Studies from the British Empire, (London \& New York: Routledge \& Kegan Paul, 2007), 62-5.

48 On the Phelps Stokes Commission on education in Western and Eastern Africa in 1924 see for example: Stephen J. Ball, 'Imperialism, Social Control and the Colonial Curriculum in Africa', Journal of Curriculum Studies, 15/3 (1983), 247; Edward H. Berman, 'American Influence on African Education: The Role of the Phelps-Stokes Fund's Education Commissions', Comparative Education Review, 15/2 (1971): 527-40; Brian Garvey, 'Colonial Schooling and Missionary Evangelism: The Case of Roman Catholic Educational Initiatives in North-Eastern Zambia, 18951953', History of Education, 23/2 (1994): 194; George E. Urch, 'Education and Colonialism in Kenya', History of Education Quarterly, 11/3 (1971): 258-9.

49 Rebekka Habermas, 'Mission im 19. Jahrhundert-Global Netze des Religiösen', Historische Zeitschrift, 287 (2008): 641.

50 On Missionary conferences see: Timothy Yates, 'Mission Conferences', in Jonathan J. Bonk (ed.), The Routledge Encyclopaedia of Missions and Missionaries, (New York and London: Routledge, 2010), 256-59. For an example of debates held about the value and use of education see: G. D. Cullen, E. Steane, J. Mullens, and H. Carre Tucker, (eds.), Conference on Missions Held in 1860 at Liverpool: Including the Papers Read, the Deliberations, and the Conclusions Reached; with a Comprehensive Index Shewing the Various Matters Brought under Review, (London: Strangeways and Walden, 1860), 111-52.

51 Clive Whitehead, 'Education Policy in British Tropical Africa: The 1925 White Paper in Retrospect', History of Education, 10/3 (1981): 195.

52 Indeed, the quantitative aspects of missionary schooling have not received much scholarly attention. At various times and in various places the number of pupils under missionary tuition fluctuated greatly. For example, Rooke suggests that only about $10.3 \%$ of the total population attended missionary schools in the British West Indies during the Apprentice period. In Fiji, according to Carmen White, a third to a half of all Fijians obtaining, or having obtained, literacy skills (mostly at missionary schools) in the 1870s. Yet, as Colin Collins has noted, many students in colonial South Africa only attended schools for a year. Such differences demonstrate the qualitative and quantitative variability of the missionary schooling, and, in order to facilitate comparative analyses, more research needs to be undertaken into the quantitative aspects of missionary education. See: Colin B. Collins, 'South Africa's First Three Hundred Years of Schooling: A Possible Re-Interpretation', History of Education Quarterly, 23/3 (1983): 365; Rooke, 'Missionaries as Pedagogues', 70; Carmen M. White, 'Historicizing Educational Disparity: Colonial Policy and Fijian Educational Attainment', History of Education, 32/4 (2003): 349. 
53 Hayden Bellenoit posited in 2007 that the field of educational sociology should be made use of to expand knowledge of 19th century Indian education, including missionary schooling, and his call can be extended to other missionary schools in the British Empire. See: Bellenoit, Missionary Education, 4.

54 See for example: John Gascoigne, 'The Expanding Historiography of British Imperialism', The Historical Journal, 49/2 (2006): 577-92.

55 The concept of hybridity, a classic term in post-colonial discourse, has not made a great impact on the research undertaken on missionary education beyond that about India, although 'cultural transfer' has.

56 The physical space of the school and its geographical location is a topic that it touched upon in studies of missionary boarding schools, especially those established in the third-quarter of the 19th century in Canada. See for example: Bain Attwood, The Making of the Aborigines, (Sydney: Allen \& Unwin, 1989); Jamie S. Scott, 'Penitential and Penitentiary: Native Canadians and Colonial Mission Education', in Jamie S. Scott and Gareth Griffiths (eds.), Mixed Messages: Materiality, Textuality, Missions, (New York: Palgrave Macmillan, 2005), 111-33. The architecture of missionary stations seen as an important reflection of their Christianizing mission: See for example: John Comaroff, and Jean Comaroff, Of Revelation and Revolution: The Dialetics of Modernity on a South African Frontier, vol. 2 (Chicago: The University of Chicago Press, 1997), 278.

\section{Bibliography}

Allender, Tim, 'Anglican Evangelism in North India and the Punjabi Missionary Classroom: The Failure to Educate the 'Masses', 1860-77', History of Education, 32/3 (2003): 273-88.

Allender, Tim, 'Bad Language in the Raj: The 'Frightful Encumbrance' of Gottlieb Leitner, 1865-1888', Paedagogica Historica, 43/3 (2007): 383-403.

Allender, Tim, 'Learning Abroad: The Colonial Educational Experiment in India, 1813-1919', Paedagogica Historica, 45/6 (2009): 727-41.

Anderson, John, The Struggle for the School. The Interaction of Missionary, Colonial Government and Nationalist Enterprise in the Development of Formal Education in Kenya (London: Longman, 1970).

Attwood, Bain, The Making of the Aborigines (Sydney: Allen \& Unwin, 1989).

Awoniyi, Timothy A., 'The Yoruba Language and the Formal School System: A Study of Colonial Language Policy in Nigeria, 1882-1952', The International Journal of African Historical Studies, 8/1 (1975): 63-80.

Bain, Rodney, 'Missionary Activity in the Bahamas, 1700-1830', in Brian Holmes (ed.), Educational Policy and the Mission Schools. Case Studies from the British Empire, 2nd edn., (London \& New York: Routledge \& Kegan Paul, 2007), 43-71.

Ball, Stephen J., 'Imperialism, Social Control and the Colonial Curriculum in Africa', Journal of Curriculum Studies, 15/3 (1983): 237-63.

Barry, Amanda, “"Equal to Children of European Origin”: Educability and the Civilising Mission in Early Colonial Australia', History Australia, 5/2 (2008): 41.1-41.16.

Bartle, George, 'The Role of the British and Foreign School Society in Elementary Education in India and the East Indies 1813-75', History of Education, 23/1 (1994): 17-33.

Bastian, Misty L., 'Young Converts: Christian Missions, Gender and Youth in Onitsha, Nigeria 1880-1929', Anthropological Quarterly, 73/3 (2000): 145-58.

Beidelman, Thomas O., 'Contradictions between the Sacred and the Secular Life: The Church Missionary Society in Ukaguru, Tanzania, East Africa, 1876-1914', Comparative Studies in Society and History, 23/1 (1981): 73-95.

Bellenoit, Hayden J. A., Missionary Education and Empire in Late Colonial India, 1860-1920 (London: Pickering \& Chatto, 2007).

Berman, Edward H., 'American Influence on African Education: The Role of the Phelps-Stokes Fund's Education Commissions', Comparative Education Review, 15/2 (1971): 132-45.

Brown, Godfrey N., 'British Educational Policy in West and Central Africa', The Journal of Modern African Studies, 2/3 (1964): 365-77.

Burnett, Kristin, 'Building the System: Churches, Missionary Organizations, the Federal State, and Health Care in Southern Alberta Treaty 7 Communities, 1890-1930', Journal of Canadian Studies, 41/3 (2007): 18-41.

Burton, Antoinette, 'Contesting the Zenana: The Mission to Make "Lady Doctors for India," 1874-1885', Journal of British Studies, 35/3 (1996): 368-97.

Campbell, James, 'Models and Metaphors: Industrial Education in the United States and South Africa', in Ran Greenstein (ed.), Comparative Perspectives on South Africa, (Houndmills, Basingstoke, Hampshire, \& London: Macmillan Press, 1998), 90-134.

Chiu, Patricia Pok-kwan, “'A Position of Usefulness”: Gendering History of Girls' Education in Colonial Hong Kong (1850s-1890s)', History of Education, 37/6 (2008): 789-805.

Collins, Colin B., 'South Africa's First Three Hundred Years of Schooling: A Possible Re-Interpretation', History of Education Quarterly 23/3 (1983): 361-78.

Comaroff, John, and Comaroff, Jean, Of Revelation and Revolution: The Dialetics of Modernity on a South African Frontier, vol. 2. (Chicago: The University of Chicago Press, 1997). 
Cox, Jeffrey, The British Missionary Enterprise since 1700 (New York and London: Routledge, 2008).

Cox, Jeffrey, 'Review of: Missionary Education and Empire in Late Colonial India, 1860-1920, by Hayden J. A. Bellenoit', Victorian Studies, 51/4 (2009): 749-51.

Cullen, G. D., Steane, E., Mullens, J., and Carre Tucker, H. (eds.), Conference on Missions Held in 1860 at Liverpool: Including the Papers Read, the Deliberations, and the Conclusions Reached; with a Comprehensive Index Shewing the Various Matters Brought under Review, (London: Strangeways and Walden, 1860).

Desai, Manali, 'Indirect British Rule, State Formation, and Welfarism in Kerala, India, 1860-1957', Social Science History, 29/3 (2005): 457-88.

Ellinghaus, Katherine, Taking Assimilation to Heart. Marriages of White Women $\mathcal{E}$ Indigenous Men in the United States $\mathcal{E}$ Australia, 1887-1937 (Lincoln \& London: University of Nebraska Press, 2006).

Etherington, Norman, 'Education and Medicine', in Norman Etheringon (ed.), Missions and Empire, (Oxford: Oxford University Press, 2005), 261-84.

Evans, Julie, Patricia Grimshaw, David Phillips, and Shurlee Swain, Equal Subjects, Unequal Rights: Indigenous Peoples in British Settler Colonies, 1830-1910 (Manchester: Manchester University Press, 2003).

Fitzgerald, Tanya, 'To Unite Their Strength with Ours', Journal of Pacific History, 39/2 (2004): 147-61.

Francis, Mark, 'The "Civilizing" of Indigenous People in Nineteenth-Century Canada', Journal of World History, 9/1 (1998): 51-87.

Frykenberg, Robert Eric, 'Modern Education in South India, 1784-1854: Its Roots and Its Role as a Vehicle of Integration under Company Raj', The American Historical Review, 91/1 (1986): 37-65.

Garvey, Brian, 'Colonial Schooling and Missionary Evangelism: The Case of Roman Catholic Educational Initiatives in North-Eastern Zambia, 1895-1953', History of Education, 23/2 (1994): 195-206.

Gascoigne, John, 'The Expanding Historiography of British Imperialism', The Historical Journal, 49/2 (2006): 577-92.

Gin, Ooi Keat, 'Sarawak Malay Attitudes Towards Education During the Period of Brooke Rule, 1841-1946', Journal of Southeast Asian Studies, 21/2 (1990): 340-59.

Goodman, Joyce, and Gary McCulloch, William Richardson, “"Empires Overseas" and "Empires at Home”: Postcolonial and Transnational Perspectives on Social Change in the History of Education', Paedagogica Historica, 45/6 (2009): 695-706.

Grant, John Webster, Moon of Wintertime. Missionaries and the Indians of Canada in Encounter Since 1534 (Toronto, Buffalo \& London: University of Toronto Press, 1984).

Habermas, Rebekka, 'Mission im 19. Jahrhundert-Global Netze des Religiösen', Historische Zeitschrift, 287 (2008): 629-79.

Haggis, Jane, “"A Heart That Has Felt the Love of God and Longs for Others to Know It": Conventions of Gender, Tensions of Self and Constructions of Difference in Offering to Be a Lady Missionary', Women's History Review, 7/2 (1998): 171-93.

Hanson, Holly Elisabeth, 'Indigenous Adaptation: Uganda's Village Schools, Ca. 1880-1937', Comparative Education Review, 54/2 (2010): 155-74.

Hilliard, David, 'Colonialism and Christianity: The Melanesian Mission in the Solomon Islands', The Journal of Pacific History, 9 (1974): 93-116.

Jensz, Felicity, 'Controlling Marriages: Friedrich Hagenauer and the Betrothal of Indigenous Western Australian Women in Colonial Victoria', Aboriginal History, 34 (2010): 35-54.

Jensz, Felicity, German Moravian Missionaries in the British Colony of Victoria, Australia, 1848-1908: Influential Strangers (Leiden: Brill, 2010).

Johnston, Anna, Missionary Writing and Empire, 1800-1860 (Cambridge: Cambridge University Press, 2003).

Jones, Richard A., 'Race and Revisability', Journal of Black Studies, 35/5 (2005): 612-32.

Kent, Eliza F., 'Tamil Bible Women and the Zenana Missions of Colonial South India', History of Religions, $39 / 2$ (1999): 117-49.

Landau, Paul, 'Language', in Norman Etherington (ed.), Mission and Empire, (Oxford, New York: Oxford University Press, 2007), 194-215.

Leach, Fiona, 'African Girls, Nineteenth-Century Mission Education and the Patriarchal Imperative', Gender and Education, 20/4 (2008): 335-47.

O'Brien, Anne, 'Creating the Aboriginal Pauper: Missionary Ideas in Early 19th Century Australia', Social Sciences \& Missions, 21/1 (2008): 6-30.

Osterhammel, Jürgen, Kolonialismus. Geschichte. Formen. Folgen, 5th edn. (München: C. H. Beck, 2006).

Prevost, Elizabeth, 'Married to the Mission Field: Gender, Christianity, and Professionalization in Britain and Colonial Africa, 1865-1914', Journal of British Studies, 47/4 (2008): 796-826.

Prevost, Elizabeth, 'Assessing Women, Gender, and Empire in Britain's Nineteenth-Century Protestant Missionary Movement', History Compass, 7/3 (2009): 765-99.

Prochner, Larry, 'Early Childhood Education Programs for Indigenous Children in Canada, Australia and New Zealand: An Historical Review', Australian Journal of Early Childhood, 29/4 (2004): 7-16. 
Prochner, Larry, and Helen May, Baljit Kaur, “"The Blessings of Civilisation”: Nineteenth-Century Missionary Infant Schools for Young Native Children in Three Colonial Settings - India, Canada and New Zealand 1820s1840s', Paedagogica Historica, 45/1\&2 (2009): 83-102.

Ramos do Ó, Jorge, 'Government of the Soul and Genesis of the Modern Educational Discourse (1879-1911)', Paedagogica Historica, 41/1\&2 (2005): 243-57.

Robert, Dana L., 'The Influence of American Missionary Women on the World Back Home', Religion and American Culture: A Journal of Interpretation, 12/1 (2002): 59-89.

Rooke, Patricia T., 'Missionaries as Pedagogues: A Reconsideration of the Significance of Education for Slaves and Apprentices in the British West Indies, 1800-1838', History of Education, 9/1 (1980): 65-79.

Scott, Jamie S., 'Penitential and Penitentiary: Native Canadians and Colonial Mission Education', in Jamie S. Scott and Gareth Griffiths (eds.), Mixed Messages: Materiality, Textuality, Missions, (New York: Palgrave Macmillan, 2005), 111-33.

Semple, Rhonda A., 'Missionary Manhood: Professionalism, Belief and Masculinity in the Nineteenth-Century British Imperial Field', Journal of Imperial \& Commonwealth History, 36/3 (2008): 397-415.

Sengupta, Parna, 'Teaching Gender in the Colony. The Education of "Outsider" Teachers in Late-NineteenthCentury Bengal', Journal of Women's History, 17/4 (2005): 32-55.

Seth, Sanjay, Subject Lessons. The Western Education of Colonial India (Durham and London: Duke University Press, 2007).

Sivonen, Seppo, White-Collar or Hoe Handle? African Education under British Colonial Policy 1920-1945 (Helsinki: Suomen Historiallinen Seura, 1995).

Stepan, Nancy, The Idea of Race in Science: Great Britain 1800-1960 (Oxford: St Antony's/Macmillan Series, 1982).

Stoler, Ann L., 'Making Empire Respectable: The Politics of Race and Sexual Morality in 20th-Century Colonial Cultures', American Ethnologist, 16/4 (1989): 634-60.

Strayer, Robert W., 'The Making of Mission Schools in Kenya: A Microcosmic Perspective', Comparative Education Review, 17/3 (1973): 313-30.

Strickrodt, Silke, 'African Girls' Samplers from Mission Schools in Sierra Leone (1820s to 1840s)', History in Africa, 37 (2010): 189-245.

Summers, Carol, " "If You Can Educate the Native Woman...”: Debates over the Schooling and Education of Girls and Women in Southern Rhodesia, 1900-1934', History of Education Quarterly, 36/4 (1996): 449-71.

Taylor, William H., 'The Presbyterian Educational Impact in Eastern Nigeria', Journal of Religion in Africa, 14/3 (1983): 223-45.

Tschurenev, Jana, 'Diffusing Useful Knowledge: The Monitorial System of Education in Madras, London and Bengal, 1789-1840', Paedagogica Historica, 44/3 (2008): 245-64.

Tschurenev, Jana, 'Incorporation and Differentiation: Popular Education and the Imperial Civilizing Mission in Early Nineteenth Century India', in Carey A. Watt and Michael Mann (eds.), Civilizing Missions in Colonial and Postcolonial South Asia. From Improvement to Development, (London: Anthem Press, 2011), 93-124.

Urch, George E., 'Education and Colonialism in Kenya', History of Education Quarterly, 11/3 (1971): $249-64$.

Watts, Ruth, 'Education, Empire and Social Change in Nineteenth Century England', Paedagogica Historica, 45/6 (2009): 773-86.

Welch, A. R., 'Aboriginal Education as Internal Colonialism: The Schooling of an Indigenous Minority in Australia', Comparative Education, 24/2 (1988): 203-15.

White, Carmen M., 'Historicizing Educational Disparity: Colonial Policy and Fijian Educational Attainment', History of Education, 32/4 (2003): 345-65.

Whitehead, Clive, 'Education Policy in British Tropical Africa: The 1925 White Paper in Retrospect', History of Education, 10/3 (1981): 195-203.

Whitehead, Clive, 'Paternalism and Educational Policy in Colonial Fiji', New Zealand Journal of Educational Studies, 16/1 (1981): 51-7.

Windel, Aaron, 'British Colonial Education in Africa: Policy and Practice in the Era of Trusteeship', History Compass, 7/1 (2009): 1-21.

Yates, Timothy, 'Mission Conferences', in Jonathan J. Bonk (ed.), The Routledge Encyclopedia of Missions and Missionaries, (New York and London: Routledge, 2010), 256-9. 